\title{
Atom Transfer Radical Polymerization of Styrene and Acrylates: Effects of Catalyst, Ligand, Solvent, and Initiator
}

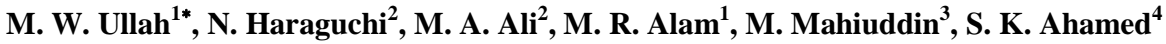 \\ ${ }^{1}$ Department of Chemistry, Faculty of Science, Comilla University, Cumilla-3506, Bangladesh \\ ${ }^{2}$ Department of Applied Chemistry and Life Science, Graduate School of Engineering, Toyohashi \\ University of Technology, 1-1 Hibarigaoka, Tempaku-cho, Toyohashi, Aichi 441-8580, Japan \\ ${ }^{3}$ Chemistry Discipline, Faculty of Science, Engineering and Technology, Khulna University, \\ Khunla-9208, Bangladesh \\ ${ }^{4}$ Department of Pharmacy, Faculty of Science, Comilla University, Cumilla-3506, Bangladesh
}

Received 6 May 2021, accepted in final revised form 3 July 2021

\begin{abstract}
Well-defined polystyrenes were successfully prepared by the $\mathrm{CuX} /(\mathrm{dN})$ bpy or $\mathrm{CuX} /$ PMDETA catalyzed atom transfer radical polymerization of styrene using 1-phenylethyl bromide (1-PEBr) or benzyl bromide (BnBr) as initiators. We found that the CuX/PMDETA catalyzed ATRP of styrene proceeded faster than $\mathrm{CuX} /(\mathrm{dN})$ bpy catalyzed counterpart in bulk, diphenyl ether (DPE) and anisole. Using $\mathrm{CuX} /(\mathrm{dN})$ bpy catalyst, well-defined polystyrenes were obtained with good chain-end functionalities and low polydispersity $\left(M_{\mathrm{w}} / M_{\mathrm{n}}<1.5\right)$ compared to CuX/PMDETA catalyst. The CuBr/PMDETA catalyzed ATRP of $n$-butyl acrylate ( $n \mathrm{BA}), n$-butyl methacrylate ( $n \mathrm{BMA})$, and tert-butyl methacrylate ( $t$ BMA) were also proceeded in a controlled manner. The molecular structure and molecular weight of polymers were determined by proton nuclear magnetic resonance $\left({ }^{1} \mathrm{H}\right.$ NMR) spectroscopy and size exclusion chromatography (SEC), respectively.
\end{abstract}

Keywords: Atom transfer radical polymerization; Well-defined polymer; Low polydispersity; Chain-end functionality.

(C) 2021 JSR Publications. ISSN: 2070-0237 (Print); 2070-0245 (Online). All rights reserved. doi: http://dx.doi.org/10.3329/jsr.v13i3.53347

J. Sci. Res. 13 (3), 999-1010 (2021)

\section{Introduction}

Free radical addition polymerization is one of the most used industrial polymerization techniques, widely used to produce a wide variety of polymeric materials such as plastics, rubbers, and fibers [1]. This method can be employed under simple conditions, and it has some advantages like insensitivity to impurities, moderate temperatures, and multiple polymerization processes. However, this method has poor control over the molecular weights and polydispersity of the resulting polymer. The preparation of well-defined polymers or copolymers with predetermined molecular weights and chain-end functionalities is complicated. To overcome these disadvantages, various

*Corresponding author: waliullah@cou.ac.bd 
controlled/“living", radical polymerizations (CRPs) such as nitroxide-mediated radical polymerization (NMP) [2,3], atom transfer radical polymerization (ATRP) [4-9], reversible addition-fragmentation chain transfer (RAFT) polymerization [10-12], single electron transfer (SET) [13], and single-electron transfer-reversible additionfragmentation chain transfer (SET-RAFT) polymerization [14-16] have been developed. Among these techniques, ATRP has become an important technique for preparing welldefined polymers because of its good control over the polymer chain length, chain-end functionalities, broad applicability to a wide range of monomers, and mild reaction conditions. It was developed independently by Matyjaszewski and Wang [4,5] and Sawamoto et al. [7] in 1995. There have been reported various well-defined homopolymers, block, and random copolymers synthesized by ATRP [4,5,17-41]. In ATRP, the ratio of monomer to the initiator in the polymer chain is used to determine the molecular weights of the resulting polymer. New advanced materials can be synthesized by varying the composition of the polymer chains and the topology of the polymer.

The controlled ATRP of styrene $[5,19,42)$ and acrylates $[4,5,43]$ have been reported using a copper-based catalytic system.

Qiu and Matyjaszewski reported the ATRP of substituted styrenes in diphenyl ether at $110{ }^{\circ} \mathrm{C}$ using the molar ratio of $[\mathrm{S}]_{\mathrm{o}} /[\mathrm{I}]_{\mathrm{o}} /[\mathrm{CuBr}]_{\mathrm{o}} /[\mathrm{bpy}]_{\mathrm{o}}=100 / 1 / 1 / 3$. The numberaverage molecular weights of poly(styrenes) were in good agreement with the calculated one, and polydispersities were relatively low $\left(M_{\mathrm{w}} / M_{\mathrm{n}}<1.5\right)$ [44].

Davis and Matyjaszewski synthesized poly( $n$-butyl methacrylate) with controlled molecular weights and low polydispersities by the CuX/PMDETA catalyzed ATRP performed in anisole setting the molar ratio of $[n \mathrm{BMA}]_{\mathrm{o}} /[\mathrm{I}]_{\mathrm{o}} /[\mathrm{CuBr}]_{\mathrm{o}} /[\mathrm{PMDETA}]_{\mathrm{o}}$ to 100/1/1/1 [45].

Krishnan's group reported the CuX/PMDETA catalyzed ATRP of $t$-butyl methacrylate ( $t \mathrm{BMA})$ in bulk and diphenyl ether. They investigated the initiator, ligand, and solvent effects on the yield and the $M_{\mathrm{n}}$ of PtBMA [46].

In the present work, we have successfully synthesized well-defined linear polymers with chain-end functionalities by the atom transfer radical polymerization (ATRP) of various monomers such as styrene $(\mathrm{S}), n$-butyl acrylate $(n \mathrm{BA}), n$-butyl methacrylate ( $n \mathrm{BMA})$, and tert-butyl methacrylate ( $t \mathrm{BMA})$ using the molar ratio of $[\text { monomer }]_{\mathrm{o}} /[\text { initiator }]_{\mathrm{o}} /[\text { copper halide }]_{\mathrm{o}} /[\text { ligand }]_{\mathrm{o}}=100 / 2 / 2 / 6$. The effects of catalyst, ligand solvent, and initiator on the yields, the molecular weights $\left(M_{\mathrm{n}}\right)$, the polydispersity $\left(M_{\mathrm{w}} / M_{\mathrm{n}}\right)$, and the chain-end functionalities were investigated in detail. These polymers were characterized by nuclear magnetic spectroscopy ( ${ }^{1} \mathrm{H}$ NMR) and size exclusion chromatography (SEC).

\section{Experimental}

\subsection{Materials and methods}

All the monomers (S, $n \mathrm{BA}, n \mathrm{BMA}$, and $t \mathrm{BMA}$ ), catalysts (copper halide $(\mathrm{CuX}, \mathrm{X}=\mathrm{Cl}$, $\mathrm{Br})$ ), and solvents (diphenyl ether, anisole) used in this study were purified according to a 
standard procedure. The ATRP ligands (2,2'-bipyridine (bpy), 4,4'-di(5-nonyl)-2,2'bipyridine (dNbpy), and $N, N, N^{\prime}, N^{\prime \prime}, N^{\prime \prime}$-pentamethyldiethylenetriamine (PMDETA)) and initiators (1-penylethyl bromide (1-PEBr) and benzyl bromide $(\mathrm{BnBr})$ ) were used as received without further purification. The ${ }^{1} \mathrm{H}$ NMR of polymers were measured in $\mathrm{CDCl}_{3}$ at $25{ }^{\circ} \mathrm{C}$ operating at $400 \mathrm{MHz}$ using the JEOL JNM-ECS 400SS spectrometer, and the chemical shifts were expressed in $\delta \mathrm{ppm}$. The molecular weights and molecular weight distributions $\left(M_{\mathrm{w}} / M_{n}\right)$ of polymers were determined by size exclusion chromatography (SEC) with Tosoh instrument with HLC $8020 \mathrm{UV}(254 \mathrm{~nm})$ detection. DMF was used as a carrier solvent at a flow rate of $1.0 \mathrm{~mL} \mathrm{~min}^{-1}$ at $40{ }^{\circ} \mathrm{C}$. Two polystyrene gel columns of bead size $10 \mu \mathrm{m}$ (Shodex KF-806L, Showa Denko K. K.) were used.

\subsection{Synthesis of function linear polymers by ATRP}

Representative synthesis procedure for polystyrene, PS: $\mathrm{CuCl}(20.4 \mathrm{mg}, 0.206 \mathrm{mmol})$, styrene (S) (1.05 g, $10.1 \mathrm{mmol})$, and diphenyl ether (DPE) $(2.5 \mathrm{~mL})$ were taken into a 6 $\mathrm{mL}$ of the vial, successively. The mixture was purged with argon for $5 \mathrm{~min}$, and then bpy (93.9 $\mathrm{mg}, 0.601 \mathrm{mmol})$ was added. $1-\mathrm{PEBr}(42.5 \mathrm{mg}, 0.230 \mathrm{mmol})$ was added as an initiator into the mixture after an additional $5 \mathrm{~min}$ of argon bubbling. The molar ratio of $[\mathrm{S}]_{\mathrm{o}} /[1-\mathrm{PEBr}]_{\mathrm{o}} /[\mathrm{CuCl}]_{\mathrm{o}} /[\mathrm{bpy}]_{\mathrm{o}}$ was set to $100 / 2 / 2 / 6$. The reaction was carried out in an oil bath at $110{ }^{\circ} \mathrm{C}$ for $24 \mathrm{~h}$ with stirring at $400 \mathrm{rpm}$. PS was precipitated by dropwise addition into $125 \mathrm{~mL}$ of methanol. The polymer mixture was again dissolved in $5 \mathrm{~mL}$ of THF and passed over an alumina column for removing copper metals. Finally, the resulting polymers were precipitated by dropwise addition into methanol, followed by filtration, and then dried in vacuo at $40{ }^{\circ} \mathrm{C}$ to afford a white powder. The molecular structure and molecular weights of PS were determined by ${ }^{1} \mathrm{H}$ NMR spectroscopy and SEC, respectively. PS: $59 \%$ yield; $M_{\mathrm{n}, \mathrm{th}}=3,260, M_{\mathrm{n}, \mathrm{SEC}}=4,040, M_{\mathrm{n}, \mathrm{NMR}}=3,930, M_{\mathrm{w}} / M_{\mathrm{n}}=$ $1.09, \mathrm{f}_{\mathrm{SEC}}=98 \%, \mathrm{f}_{\mathrm{NMR}}=74 \%$.

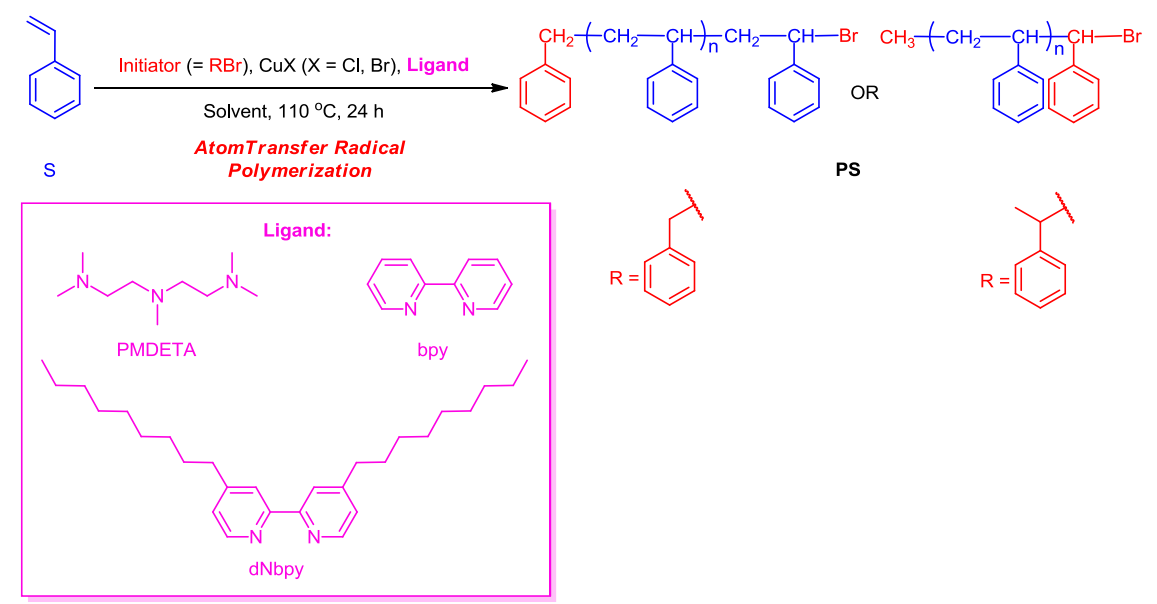

Scheme 1. Synthesis of PS by ATRP. 
$\boldsymbol{P n B A}: 53 \%$ yield; $M_{\mathrm{n}, \mathrm{th}}=3,580, M_{\mathrm{n}, \mathrm{SEC}}=7,830, M_{\mathrm{w}} / M_{\mathrm{n}}=1.47$.

PnBMA: $48 \%$ yield; $M_{\mathrm{n}, \mathrm{th}}=3,600, M_{\mathrm{n}, \mathrm{SEC}}=5,450, M_{\mathrm{w}} / M_{\mathrm{n}}=1.15$.

PtBMA: PtBMA was collected by the precipitation into $125 \mathrm{~mL}$ of a ratio of methanol and water (1/1). The polymer mixture was dissolved in $5 \mathrm{~mL}$ of THF and passed over the alumina column for removing copper metals. Finally, the resulting PtBMA was precipitated by dropwise addition in a $1 / 1 \mathrm{MeOH} / \mathrm{H}_{2} \mathrm{O}$ mixed solvent, followed by filtration, and then dried in vacuo at $40{ }^{\circ} \mathrm{C}$ to provide a white powder. Yield: $39 \% ; M_{\mathrm{n} \text {, th }}=$ $2,960, M_{\mathrm{n}, \mathrm{SEC}}=6,190, M_{\mathrm{w}} / M_{\mathrm{n}}=1.24$.

\section{Results and Discussion}

\subsection{Synthesis of linear polystyrene (PS) by the atom transfer radical polymerization of styrene $(S)$}

PS was synthesized by the ATRP of S, as illustrated in Scheme 1. The effects of catalyst, ligand, solvent, and initiator on the yield, the polydispersity, and the chain-end functionalities were outlined in Table 1 .

Table 1. Effects of catalyst, ligand, solvent, and initiator on ATRP of styrene. ${ }^{\text {a }}$

\begin{tabular}{|c|c|c|c|c|c|c|c|c|c|c|}
\hline \multirow[t]{2}{*}{ Entry } & \multirow[t]{2}{*}{ Solvent } & \multirow[t]{2}{*}{ Ligand } & \multirow[t]{2}{*}{ Catalyst } & \multirow{2}{*}{$\begin{array}{c}\text { Yield } \\
(\%)\end{array}$} & \multirow[t]{2}{*}{$M_{\mathrm{n}, \mathrm{th}}$} & \multirow[t]{2}{*}{$M_{\mathrm{n}, \mathrm{SEC}}{ }^{\mathrm{b}}$} & \multirow[t]{2}{*}{$M_{\mathrm{n}, \mathrm{NMR}}{ }^{\mathrm{c}}$} & \multirow[t]{2}{*}{$M_{\mathrm{w}} / M_{n}{ }^{\mathrm{b}}$} & \multicolumn{2}{|c|}{$\begin{array}{c}\text { Degree of } \\
\text { Functionality }(\%)\end{array}$} \\
\hline & & & & & & & & & SEC & NMR \\
\hline 1 & Bulk & PMDETA & $\mathrm{CuBr}$ & 93 & 5,030 & 4,380 & 4,760 & 1.23 & 21 & 22 \\
\hline 2 & DPE & PMDETA & $\mathrm{CuBr}$ & 81 & 4,400 & 4,470 & 4,240 & 1.27 & 40 & 38 \\
\hline 3 & DPE & PMDETA & $\mathrm{CuCl}$ & 85 & 4,610 & 4,570 & 4,400 & 1.25 & 21 & 27 \\
\hline 4 & Anisole & PMDETA & $\mathrm{CuBr}$ & 89 & 4,820 & 6,960 & 7,000 & 1.61 & 52 & 50 \\
\hline 5 & Bulk & bpy & $\mathrm{CuBr}$ & 71 & 3,880 & 3,530 & 3,310 & 1.16 & 99 & 73 \\
\hline 6 & DPE & $(\mathrm{dN})$ bpy & $\mathrm{CuBr}$ & 54 & 3,000 & 3,070 & 2,980 & 1.06 & 99 & 75 \\
\hline 7 & DPE & bpy & $\mathrm{CuCl}$ & 59 & 3,260 & 4,040 & 3,930 & 1.09 & 98 & 74 \\
\hline $8^{\mathrm{d}}$ & DPE & bpy & $\mathrm{CuBr}$ & 41 & 2,310 & 3,030 & - & 1.06 & 97 & - \\
\hline $9^{\mathrm{e}}$ & DPE & bpy & $\mathrm{CuBr}$ & 38 & 4,140 & 4,020 & 3,900 & 1.06 & 92 & 81 \\
\hline
\end{tabular}

${ }^{a}$ Polymerizations were conducted out at $110^{\circ} \mathrm{C}$ for $24 \mathrm{~h}$. S/1-PEBr/CuX/PMDETA(bpy) = 100/2/2/6.

$M_{\mathrm{n}, \mathrm{th}}=\left[\left\{(\mathrm{MW})_{\mathrm{S}} \times\right.\right.$ Conversion $\left.\left.\times\left([\mathrm{S}]_{\mathrm{o}} /[1-\mathrm{PEBr}]_{\mathrm{o}}\right)\right\}+(\mathrm{MW})_{1-\mathrm{PEBr}}\right]$.

${ }^{\mathrm{b}}$ Determined by SEC.

${ }^{c}$ Determined by ${ }^{1} \mathrm{H}$ NMR spectroscopy.

${ }^{\mathrm{d}} \mathrm{BnBr}$ was used as an initiator instead of $1-\mathrm{PEBr}$.

${ }^{\mathrm{e}} \mathrm{S} / 1-\mathrm{PEBr} / \mathrm{CuBr} / \mathrm{bpy}=100 / 1 / 1 / 3$ (molar ratio).

\subsubsection{Effect of catalyst in the polymerization of styrene}

The effect of copper halide $(\mathrm{CuX}, \mathrm{X}=\mathrm{Cl}, \mathrm{Br})$ and PMDETA/bpy ligand-based catalysts in the ATRP of styrene performed in bulk or DPE was investigated using 1-PEBr as an initiator. The yield was increased when polymerization with $\mathrm{CuBr} / \mathrm{PMDETA}$ catalyst was conducted in bulk. On the other hand, the chain-end functionalities were lost compared to DPE, probably due to the chain termination (entry 2 vs 1 ). CuCl/PMDETA catalyst with 1-PEBr affects the yield of polymers compared to $\mathrm{CuBr} / \mathrm{PMDETA}$ (entries 2 and 3), and the polydispersity index $\left(M_{\mathrm{w}} / M_{\mathrm{n}}\right)$ was slightly low. The yield of polymers was also 
enhanced when $\mathrm{CuCl}$ was used instead of $\mathrm{CuBr}$ with bpy (entries 6 and 7). $\mathrm{CuCl}$ with 1$\mathrm{PEBr}$ showed high efficiency than $\mathrm{CuBr}$ with $1-\mathrm{PEBr}$ in the ATRP of $\mathrm{S}$. This mixed halogen system was assisted in decreasing the propagating rate since $\mathrm{R}-\mathrm{Cl}$ has a stronger $\mathrm{C}-\mathrm{X}$ bond than $\mathrm{R}-\mathrm{Br}[47-50]$.

\subsubsection{Effect of ligand}

The complex formed from PMDETA with $\mathrm{CuX}$ showed higher reactivity than (dN)bpy in bulk and DPE due to its lower redox potential [51]. By contrast, when bpy or dNbpy was used as a ligand with $\mathrm{CuX}$, higher chain-end functionalities were obtained, and the $M_{\mathrm{w}} / M_{\mathrm{n}}$ values were relatively lower than in CuX/PMDETA catalyst (entry 1 vs. 5; entry 2 vs. 6; entry 3 vs. 7). The $M_{\mathrm{n}}$ of PS was in good agreement with that calculated when the $\mathrm{CuX} / \mathrm{PMDETA}$ or $\mathrm{CuX} /(\mathrm{dN})$ bpy catalyzed ATRP was employed in bulk or DPE.

\subsubsection{Effect of solvent}

The yield of polymers in anisole, DMF (not reported due to low conversion), and DPE were comparable with $\mathrm{CuBr} / \mathrm{PMDETA}$ catalyst system. In anisole, the $M_{\mathrm{n}}$ of PS with a high polydispersity $\left(M_{\mathrm{w}} / M_{\mathrm{n}}=1.61\right)$ was somewhat higher than that calculated due to the bimolecular termination at the early stage of the polymerization (entries 2 and 4).

\subsubsection{Effect of initiator}

When $\mathrm{BnBr}$ initiator was used instead of $1-\mathrm{PEBr}$ in the ATRP of styrene, low reactivity was observed due to the formation of less active $1^{\circ}$ radicals during polymerization. The yield of $\mathbf{P S}$ in polymerization using the molar ratio of $1-\mathrm{PEBr} / \mathrm{CuBr} / \mathrm{bpy}(=2 / 2 / 6)$ was higher than that using the ratio was $1 / 1 / 3$ (entries 6 and 9).

From these results, the combination of bpy or dNbpy as a ligand and DPE as a solvent were the suitable ATRP conditions for the synthesis of well-defined PS with good chainend functionalities.

The ${ }^{1} \mathrm{H}$ NMR spectra of PS are shown in Fig. 1. In all spectra, signals at 1.42, 1.85, and 6.20-7.23 ppm were observed for methylene (a), methine (b), and phenyl (c) protons, respectively. The signals that appeared at 1.10 and 4.20-4.62 ppm indicated the presence of methyl $\left(-\mathrm{CH}_{3}\right)$ and methine protons with bromine atom $(-\mathrm{C} \underline{\mathrm{HBr}})$ at the chain end of PS. The signals for phenyl protons in the initiator moiety were overlapped with those of phenyl protons (c) in the styrene repeating units. 


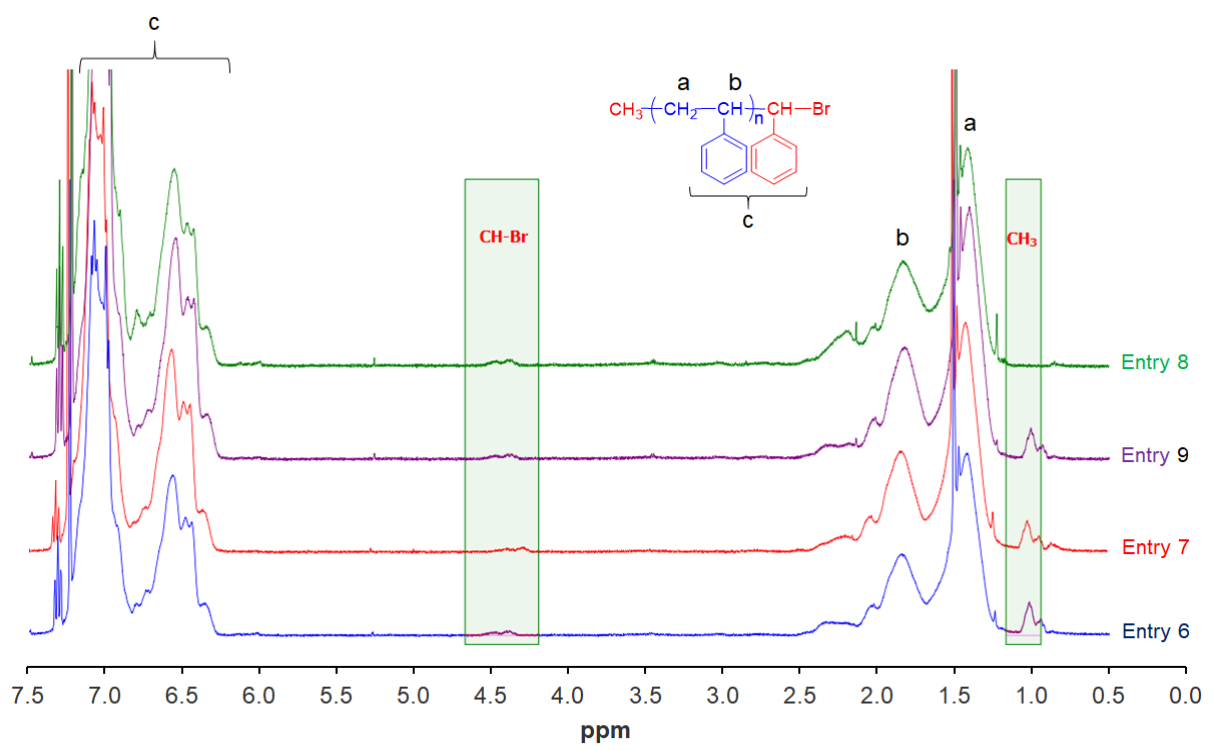

Fig. 1. ${ }^{1} \mathrm{H}$ NMR spectra of $\mathbf{P S}$ in $\mathrm{CDCl}_{3}$.

Fig. 2 shows the SEC traces of the 1-PEBr initiated ATRP of styrene. The molecular weight distributions (MWD) were narrowed in the SEC traces, i.e., the low polydispersity indexes $\left(M_{w} / M_{n}\right)$. When the ATRP of styrene was carried out in anisole, the molecular weight distributions of PS were slightly broader (entry 4). These results indicated that well-defined PS with good chain-end functionalities were successfully synthesized by ATRP.

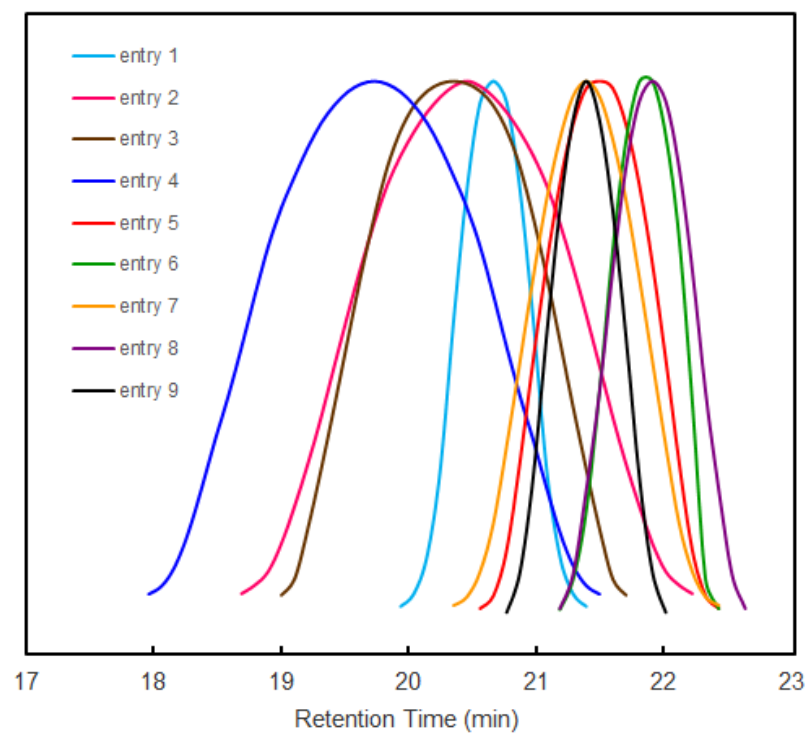

Fig. 2. SEC traces of PS. 

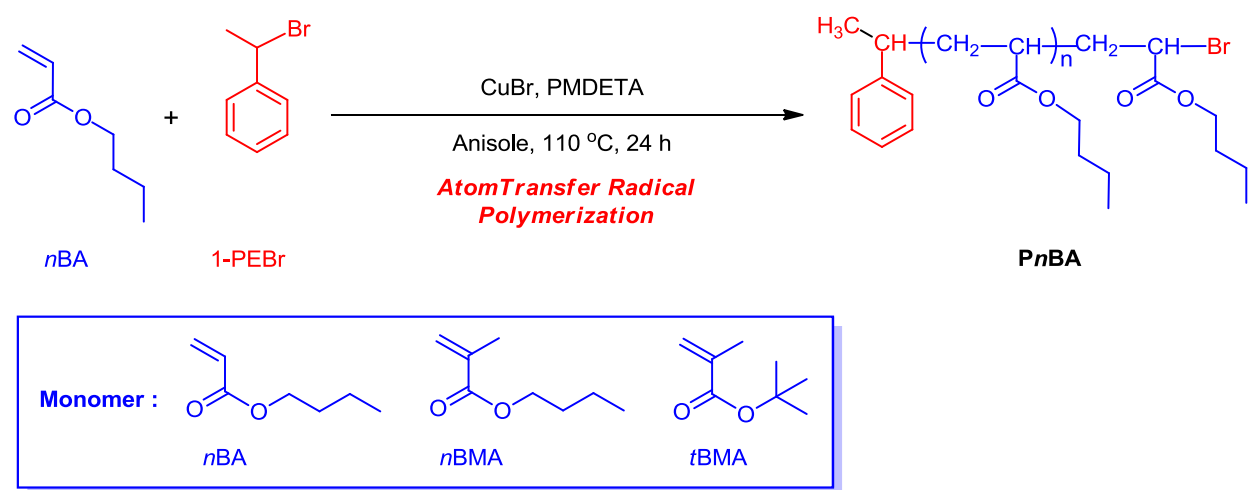

Scheme 2. Synthesis of polyacrylates by ATRP.

Table 2. Characterization of polyacrylates synthesized by ATRP. ${ }^{a}$

\begin{tabular}{llllccc}
\hline Entry & Polymer & Monomer & Yield $(\%)$ & $M_{\mathrm{n}, \mathrm{th}}$ & $M_{\mathrm{n}, \mathrm{SEC}}{ }^{\mathrm{b}}$ & $M_{\mathrm{w}} / M_{n}{ }^{b}$ \\
\hline 1 & P $n \mathrm{BA}$ & $n \mathrm{BA}$ & 53 & 3,580 & 7,830 & 1.47 \\
2 & P $n$ BMA & $n \mathrm{BMA}$ & 48 & 3,600 & 5,450 & 1.15 \\
3 & P $t$ BMA & $t$ BMA & 39 & 2,960 & 6,190 & 1.24 \\
\hline
\end{tabular}

${ }^{\text {a }}$ Polymerizations were conducted out in anisole at $110{ }^{\circ} \mathrm{C}$ for $24 \mathrm{~h} . \mathrm{M} / 1-\mathrm{PEBr} / \mathrm{CuBr} / \mathrm{PMDETA}=100 / 2 / 2 / 6$.

$M_{\mathrm{n}, \text { th }}=\left[\left\{(\mathrm{MW})_{\mathbf{M}} \times\right.\right.$ Conversion $\left.\times\left([\mathbf{M}]_{\mathrm{o}}\left[[1-\mathrm{PEBr}]_{\mathrm{o}}\right)\right\}+(\mathrm{MW})_{1-\mathrm{PEBr}}\right]$.

${ }^{\mathrm{b}}$ Determined by SEC.

\subsection{Synthesis of polyacrylates by ATRP}

The polymerization system could be changed according to the monomer type of ATRP and SI-ATRP [52,53]. PMDETA as a ligand and anisole as a solvent was chosen for the ATRP of acrylate monomers ( $n \mathrm{BA}, n \mathrm{BMA}$, and $t \mathrm{BMA}$ ) (Scheme 2). The characterization data were summarized in Table 2.

For the catalyst system, $\mathrm{CuBr} / \mathrm{PMDETA}$ catalyzed was more suitable than $\mathrm{CuBr} / \mathrm{bpy}$ or $\mathrm{CuBr} / \mathrm{dNbpy}$ in the ATRP [29,54] of (meth)acrylates. Low polydispersity indexes $\left(M_{\mathrm{w}} / M_{\mathrm{n}}\right)$ in the ATRP of (meth)acrylate monomers were obtained when CuBr/PMDETA catalyst was used in anisole as a solvent instead of DPE. In PnBA, PnBMA, and PtBMA, the $M_{\mathrm{n}}$ of the polymer chains were slightly higher than that calculated due to the bimolecular termination at the early stage of the polymerization. The polydispersity indexes $\left(M_{\mathrm{w}} / M_{\mathrm{n}}\right)$ were low. 


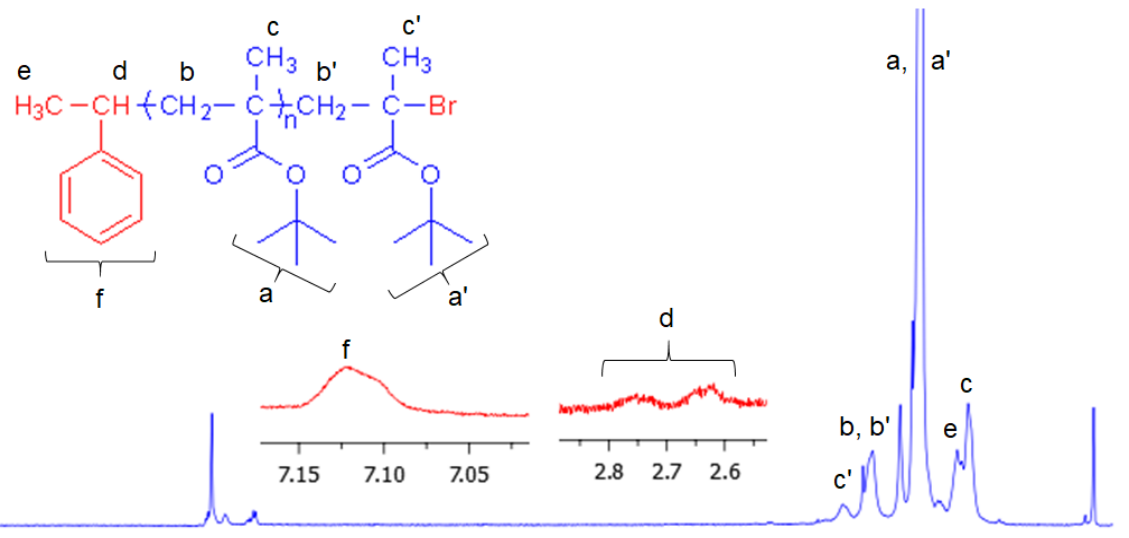

PtBMA
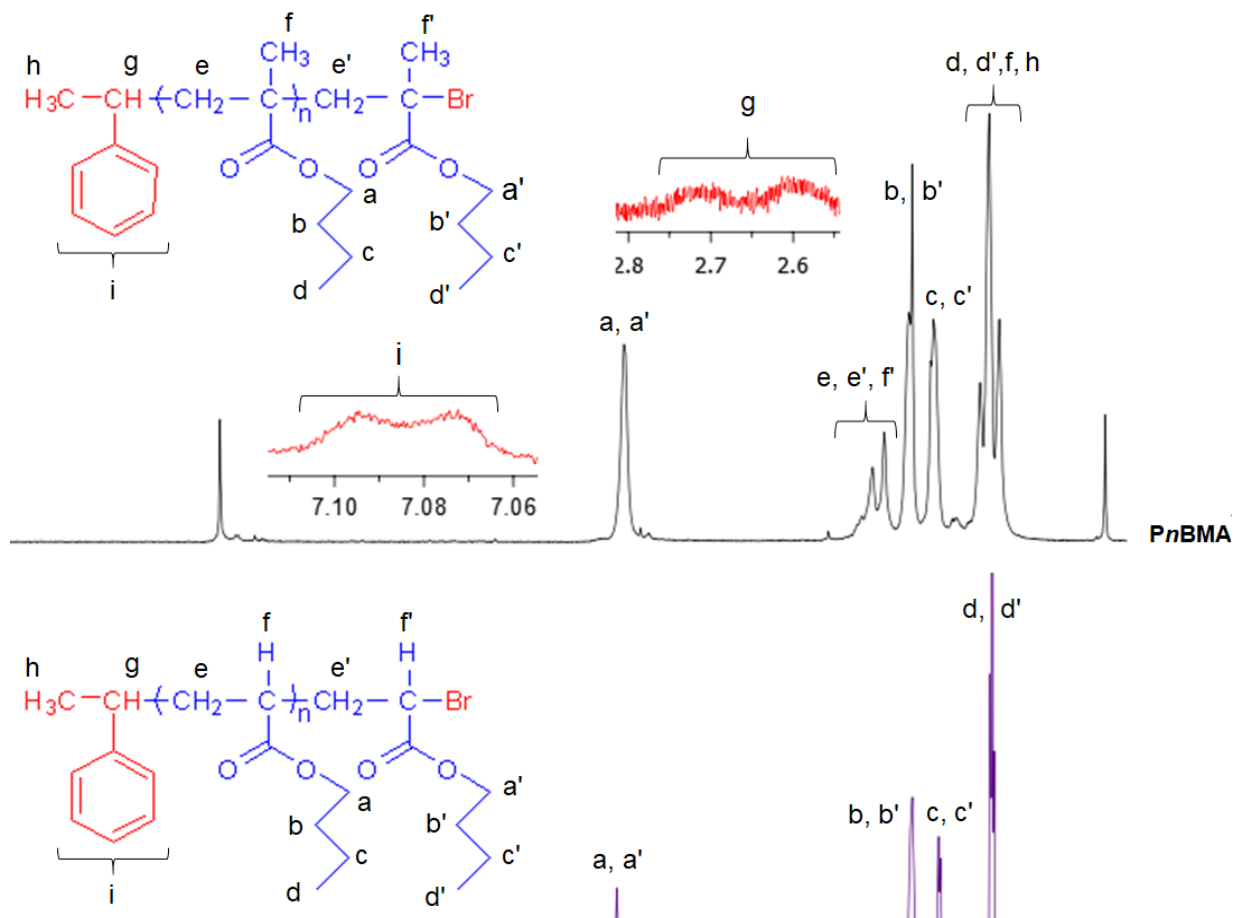

$\mathrm{d}, \mid \mathrm{d}^{\prime}$
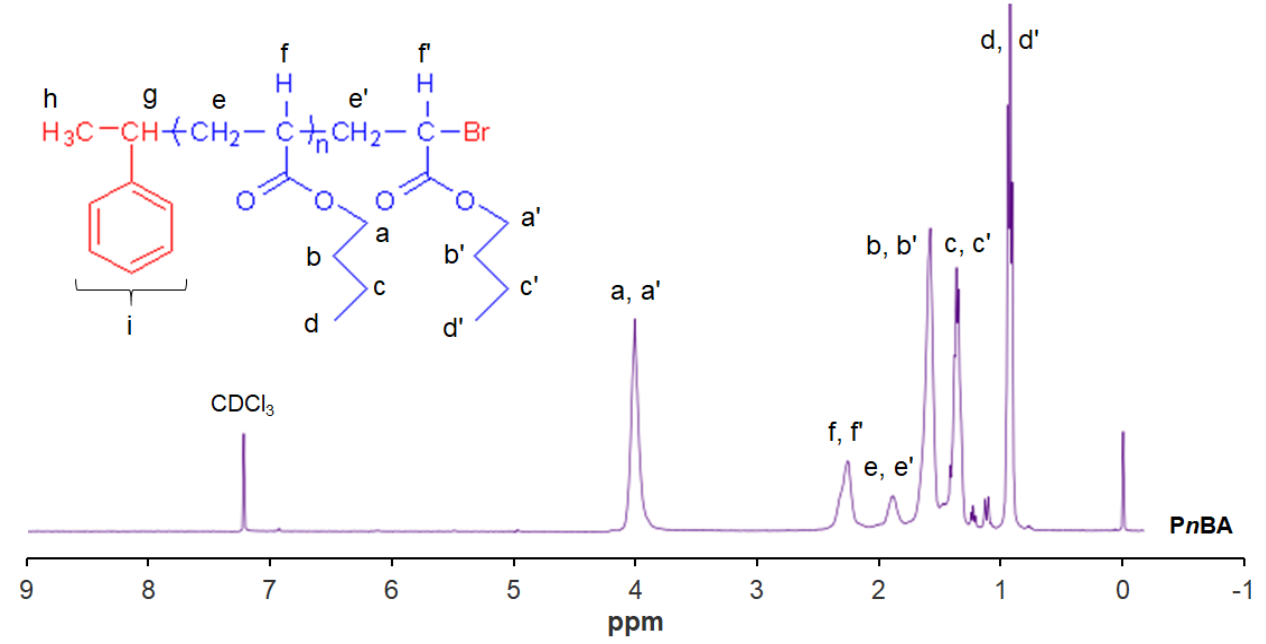

Fig. 3. ${ }^{1} \mathrm{H}$ NMR spectra of PnBA, PnMBA, and PtBMA in $\mathrm{CDCl}_{3}$. 
Fig. 3 shows the ${ }^{1}$ H NMR spectra of PnBA, PnBMA, and PtBMA. In the NMR spectrum of PnBA, the signals at 2.28 and $1.88 \mathrm{ppm}$ are the characteristic methine (f) and methylene (e) protons in the $n \mathrm{BA}$ repeating units. The signals observed at 4.04, 1.61, 1.36, and 0.94 ppm are corresponding to $-\mathrm{OC}_{2}(\mathrm{a}),-\underline{\mathrm{CH}}_{2}(\mathrm{~b}),-\underline{\mathrm{C}}_{2}$ (c), and $-\underline{\mathrm{C}}_{3}$ (d) protons in the butyl group, respectively. In the NMR spectrum of PnBMA, the peaks due to methylene (e) and two different methyl $(\mathrm{d}, \mathrm{f})$ protons were observed at 1.81-1.91 and 0.87-1.03 ppm, respectively. The signals that appeared at 3.98, 1.61, and $1.43 \mathrm{ppm}$ indicated $\mathrm{OCH}_{2},-\underline{\mathrm{CH}}_{2}$ (b), and $-\mathrm{CH}_{2}$ (c) protons of the butyl group, respectively. The characteristic signals for the phenyl (i) and methine $(\mathrm{g})$ protons of the initiator were found at 7.06-7.12 and 2.50-2.80 ppm, respectively. The signals of the methyl (h) and $-\mathrm{C}\left(\mathrm{CH}_{3}\right) \mathrm{Br}$ group ( $\left.\mathrm{f}^{\prime}\right)$ protons at the chain ends were overlapped with the signals of the methyl (d, f) and methylene (e) protons in the repeating units. In the NMR spectrum of PtBMA, the signals for the methylene (b) and methyl (a, c) protons were appeared at 1.82, 1.44, 1.03 ppm, respectively. The presence of methyl (e), methine (d), and phenyl (f) protons in the initiator moiety and the $-\mathrm{C}\left(\mathrm{C}_{3}\right) \mathrm{Br}$ protons at the chain end were confirmed by the signals observed at $1.12,2.50-2.80$, and 7.05-7.15 ppm (in the magnified spectra) and $2.06 \mathrm{ppm}$, respectively. On the other hand, in the magnified spectra of PnBA (not shown in Fig. 3), the signal intensity (h, g, i) of the initiator moiety and methine protons with bromine atom $(-\mathrm{C} \underline{\mathrm{HBr}})$ at the chain end was lower compared to PnBMA and PtBMA.

The SEC traces of PnBA, PnBMA, and PtBMA are shown in Fig. 4. In SEC traces, the molecular weight distributions (MWD) of polymers were narrowed.

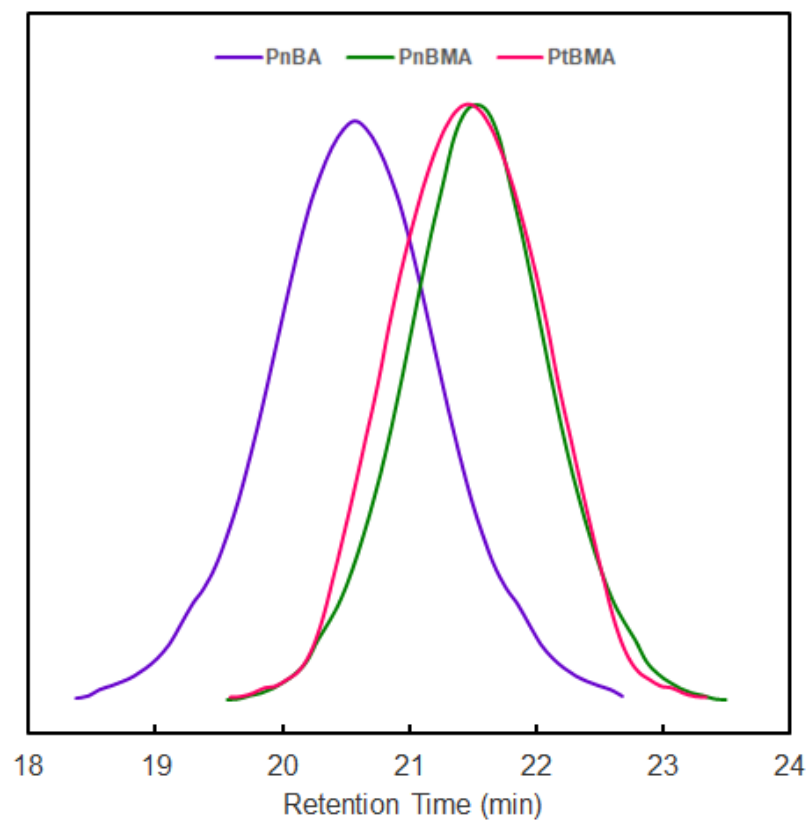

Fig. 4. SEC traces of PnBA, PnBMA, and PtBMA. 
These results indicated that well-defined PnBMA and PtBMA with chain-end functionalities were successfully prepared by the CuBr/PMDETA catalyzed ATRP using $1-\mathrm{PEBr}$ as an initiator in anisole.

\section{Conclusion}

Well-defined polymers were synthesized by the CuX/PMDETA(bpy) catalyzed atom transfer radical polymerization of vinyl monomers such as styrene, $n$-butyl acrylate $(n \mathrm{BA}), n$-butyl methacrylate ( $n \mathrm{BMA})$, and tert-butyl methacrylate ( $t \mathrm{BMA})$ using 1phenylethyl bromide as an initiator in bulk and solution. The effects of catalyst, ligand, solvent, and initiator on the yield, the molecular weights $\left(M_{\mathrm{n}}\right)$, the polydispersity $\left(M_{\mathrm{w}} / M_{\mathrm{n}}\right)$, and the chain-end functionalities were investigated. We found that the CuX/PMDETA catalyzed ATRP of styrene proceeded faster in bulk, diphenyl ether, and anisole than the $\mathrm{CuX} /(\mathrm{dN})$ bpy catalyzed counterpart. Using $\mathrm{CuX} /(\mathrm{dN})$ bpy catalyst, PS were obtained with good chain-end functionalities and low polydispersity $\left(M_{\mathrm{w}} / M_{\mathrm{n}}<1.5\right)$ compared to CuX/PMDETA catalyst. The CuBr/PMDETA catalyzed ATRP of $n$-butyl acrylate ( $n \mathrm{BA})$, $n$-butyl methacrylate ( $n \mathrm{BMA})$, and tert-butyl methacrylate ( $t \mathrm{BMA})$ were also proceeded in anisole in a controlled manner. The molecular structure of polymers with chain-end functionalities and the $M_{\mathrm{n}}$ of polymers with molecular weight distributions $\left(M_{\mathrm{w}} / M_{\mathrm{n}}\right)$ were determined by nuclear magnetic resonance $\left({ }^{1} \mathrm{H}\right.$ NMR) spectroscopy and size exclusion chromatography (SEC), respectively.

\section{References}

1. G. Moad and D. H. Solomon, The Chemistry of Free Radical Polymerization (PergamonElsevier Science, Oxford, 1995).

2. M. K. Georges, R. P. N. Veregin, P. M. Kazmaier, and G. K. Hamer, Macromolecules 26, 2987 (1993). https://doi.org/10.1021/ma00063a054

3. R. D. Puts and D. Y. Sogah, Macromolecules 29, 3323 (1996). https://doi.org/10.1021/ma0011946

4. J.-S. Wang and K. Matyjaszewski, J. Am. Chem. Soc. 117, 5614 (1995). https://doi.org/10.1021/ja00125a035

5. J.-S. Wang and K. Matyjaszewski, Macromolecules 28, 7901 (1995). https://doi.org/10.1021/ma00127a042

6. J.-S. Wang and K. Matyjaszewski, Macromolecules 28, 7572 (1995). https://doi.org/10.1021/ma00126a041

7. M. Kato, M. Kamigaito, M. Sawamoto, and T. Higashimura, Macromolecules 28, 1721 (1995). https://doi.org/10.1021/ma00109a056

8. K. Matyjaszewski, ACS Symp. Ser. 685, 258 (1998). https://doi.org/10.1021/bk-1998$\underline{0685 . \operatorname{ch} 016}$

9. K. Matayjaszewski and J. Xia, Chem. Rev. 101, (2001). https://doi.org/10.1021/cr940534g

10. J. Chiefari, Y. K. Chong, F. Ercole, J. Krstina, J. Jeffery, T. P. T. Le, R. T. A. Mayadunne, G. F. Meijs, C. L. Moad, G. Moad, E. Rizzardo, and S. H. Thang, Marcomolecules 31, 5559 (1998). https://doi.org/10.1021/ma9804951

11. T. P. Le, G. Moad, E. Rizzardo, and S. H. Thang, Chem. Abstr. 128, 115 (1998).

12. Y. K. Chong, T. P. T. Le, G. Moad, E. Rizzardo, and S. H. Thang, Macromolecules 32, 2071 (1999). https://doi.org/10.1021/ma981472p 
13. V. Percec, T. Guliashvili, J. S. Ladislaw, A. Wistrand, A. Stjerndahl, M. J. Sienkowska, M. J. Monteiro, and S. Sahoo, J. Am. Chem. Soc. 128, 14156 (2006).

https://doi.org/10.1021/ja065484z

14. S. H. Subramanian, R. Prakash Babu, and R. Dhamodharan, Macromolecules 41, 262 (2008). https://doi.org/10.1021/ma7021056

15. N. Haridharan, K. Ponnusamy, and R. Dhamodharan, J. Polym. Sci Part A: Polym. Chem. 48, 5329 (2010). https://doi.org/10.1002/pola.24333

16. W. Zhang, W. Zhang, Z. Zhang, J. Zhu, and X. Zhu, Macromol. Rapid Commun. 31, 1354 (2010). https://doi.org/10.1002/marc.201000008

17. Y. Kotani, M. Kato, M. Kamigaito, and M, Sawamoto, Macromolecules 29, 6969 (1996). https://doi.org/10.1021/ma960768x

18. C. Granel, P. Dubois, R. Jerome, and P. Teyssie, Macromolecules 29, 8576 (1996). https://doi.org/10.1021/ma9608380

19. K. Matyjaszewski, T. E. Patten, and J. Xia, J. Am. Chem. Soc. 119, 674 (1997). https://doi.org/10.1021/ja963361g

20. D. Haddleton, D. Kukulji, D. J. Duncalf, A. M. Heming, and A. J. Shooter, Macromolecules 31, 5201 (1998). https://doi.org/10.1021/ma980437f

21. K. L. Beers, S. G. Gaynor, K. Matyjaszewski, S. S. Sheiko, and M. Moeller, Macromolecules 31, 9413 (1998). https://doi.org/10.1021/ma981402i

22. S. Coca, C. B. Jaszieczek, K. L. Beers, and K. Matyjaszewski, J. Polym. Sci. Part A: Polym. Chem. 36, 1417 (1998). https://doi.org/10.1002/(SICI)1099-0518(19980715)36:9<1417::AIDPOLA9>3.0.CO;2-P

23. Y. Kotani, M. Kamigaito, and M. Sawamoto, Macromolecules 31, 5582 (1998). https://doi.org/10.1021/ma980294x

24. S. V. Arehart and K. Matyjaszewski, Macromolecules 32, 2221 (1999). https://doi.org/10.1021/ma981693v

25. E. J. Ashford, V. Naldi, R. O’Dell, N. C. Billingham, and S. P. Armes, Chem. Comm. 14, 1285 (1999). https://doi.org/10.1039/a903773j

26. C. Moineau, M. Minet, P. Teyssie, and R. Jerome, Macromolecules 32, 8277 (1999). https://doi.org/10.1021/ma990783c

27. S. Pascual, B. Coutin, M. Tardi, A. Polton, and J. P. Varion, Macromolecules 32, 1432 (1999). https://doi.org/10.1021/ma9813410

28. P. Leclere, G. Moineau, M. Minet, P. Dubois, R. Jerome, J. L. Bredas, and R. Lazzaroni, Langmuir 15, 3915 (1999). https://doi.org/10.1021/la981273z

29. K. A. Davis and K. Matyjaszewski, Macromolecules 33, 4039 (2000). https://doi.org/10.1021/ma991826s

30. K. A. Davis, B. Charleux, and K. Matyjaszewski, J. Polym. Sci. Part A: Polym. Chem. 38, 2274 (2000). https://doi.org/10.1002/(SICI)1099-0518(20000615)38:12<2274::AIDPOLA170>3.0.CO;2-I

31. N. J. Hovestad, G. Koten, S. Van, A. F. Bon, and M. D. Haddleton, Macromolecules 33, 4048 (2000). https://doi.org/10.1021/ma991908g

32. K. Matyjaszewski, D. A. Shipp, G. P. McMurtry, S. G. Gaynor, and T. Pakula, J. Polym. Sci Part A: Polym. Chem. 38, 2023 (2000). https://doi.org/10.1002/(SICI)1099-0518(20000601)38:11\%3C2023::AID-POLA110\%3E3.0.CO;2-L

33. K. Matyjaszewski, M. J. Ziegler, S. V. Arehart, D. Greszta, and T. J. Pakula, Phys. Org. Chem. 13, 775 (2000). https://doi.org/10.1002/1099-1395(200012)13:12<775::AIDPOC314>3.0.CO;2-D

34. K, A. Davis and K. Matyjaszewski, Adv. Polym. Sci. 159, 2 (2002). https://doi.org/10.1007/3$\underline{540-45806-9}$

35. J. Qiu, B. Charleux and K. Matyjaszewski, Progr. Polym. Sci. 26, 2083 (2001). https://doi.org/10.1016/S0079-6700(01)00033-8

36. J. F. Lutz, D. Neugebauer, and K. Matyjaszewski, J. Am. Chem. Soc. 125, 6986 (2003). https://doi.org/10.1021/ja029517w 
37. M. Li and K. Matyjaszewski, Macromolecules 36, 6028 (2003). https://doi.org/10.1021/ma034109d

38. S. C. Hong, D. Neugebauer, Y. Inoue, J. F. Lutz, and K. Matyjaszewski, Macromolecules 36, 27 (2003). https://doi.org/10.1021/ma0214299

39. S. C. Hong, J. F. Lutz, Y. Inoue, C. Strissel, O. Nuyken, and K. Matyjaszewski, Macromolecules 36, 1075 (2003). https://doi.org/10.1021/ma021235t

40. I. S. Chung and K. Matyjaszewski, Macromolecules 36, 2995 (2003). https://doi.org/10.1021/ma034029

41. N. V. Tsarevsky, T. Sarbu, B. Goebelt, and K. Matyjaszewski, Macromolecules 35, 6142 (2002). https://doi.org/10.1021/ma020560d

42. V. Percec and B. Barboiu, Macromolecules 28, 7970 (1995). https://doi.org/10.1021/ma00127a057

43. K. A. Davis, H.-J Paik, and K. Matyjaszewski, Macromolecules 32, 1767 (1999). https://doi.org/10.1021/ma9815051

44. J. Qiu and K. Matyjaszewski, Macromolecules 30, 5643 (1997). https://doi.org/10.1021/ma9704222

45. K. A. Davis and K. Matyjaszewski, Chinese J. Polym. Sci. 22, 195 (2004). http://www.cjps.org/fileGFZKX/journal/article/cjps/2004/2/PDF/04020195.pdf

46. R. Krishnan and K. V. S. Srinivasan, Eur. Polym. J. 40, 2269 (2004). https://doi.org/10.1016/j.eurpolymj.2004.06.010

47. X. S. Wang, N. Luo, and S. K. Ying, J. Polym. Sci. Part A: Polym. Chem. 37, 1255 (1999). https://doi.org/10.1002/(SICI)1099-0518(19990501)37:9\%3C1255::AID-POLA5\%3E3.0.CO;2-O

48. A. Goto and T. Fukuda, Macromol. Rapid Commun. 20, 633 (1999). https://doi.org/10.1002/(SICI)1521-3927(19991201)20:12\%3C633::AID-MARC633\%3E3.0.CO;2-2

49. K. Matyjaszewski, D. A. Shipp, J. L. Wang, T. Grimaud, and T. E. Patten, Macromolecules 31, 6836 (1998). https://doi.org/10.1021/ma980476r

50. D. M. Haddleton, A. M. Heming, D. Kukulj, and S. G. Jackson, Chem. Comm. 1, 1719 (1998). https://doi.org/10.1039/A804046J

51. J. Qiu, K. Matyjaszewski, L. Thouin, and Ch. Amatore, Macromol. Chem. Phys. 201, 1625 (2000). https://doi.org/10.1002/1521-3935(20000901)201:14\%3C1625::AID-MACP1625\%3E3.0.CO;2-9

52. M. W. Ullah and N. Haraguchi, J. Polym. Sci. Part A: Polym. Chem. 57, 1296 (2019). https://doi.org/10.1002/pola.29389

53. M. W. Ullah, N. T. P. Thao, T. Sugimoto, and N. Haraguchi, Mol. Catal. 473, 110392 (2019). https://doi.org/10.1016/j.mcat.2019.110392

54. J. Xia and K. Matyjaszewski, Macromolecules 30, 7697 (1997). https://doi.org/10.1021/ma971009x 